\title{
Possible Sources of Trigger Mechanism of Electron-phonon Interactions in Doped CuTl-1223 Superconductors
}

Anila Kanwal ( $\sim$ anilakanwal2016@gmail.com )

Quaid-i-Azam University Islamabad: Quaid-i-Azam University

Nawazish Ali Khan

Quaid-i-Azam University Islamabad: Quaid-i-Azam University

Research Article

Keywords: Charge reservoir layer (CRL), Doped Cuprates Superconductors, charge density waves, spin density waves

Posted Date: November 5th, 2021

DOI: https://doi.org/10.21203/rs.3.rs-1031048/v1

License: (c) (i) This work is licensed under a Creative Commons Attribution 4.0 International License. Read Full License 


\section{Abstract}

This article underlines the important role of copper $\mathrm{Cu}\left(3 \mathrm{~d}^{9}\right)$ spins at the $\mathrm{CuO}_{2}$ planer sites to comprehend the physics of High temperature Superconductivity . In such studies we have reported the characterization results of samples $\left(\mathrm{Cu}_{0.5} \mathrm{TI}_{0.5}\right) \mathrm{Ba}_{2} \mathrm{Ca}_{2} \mathrm{Cu}_{3} \mathrm{O}_{10-\delta}$, $\left(\mathrm{Cu}_{0.5} \mathrm{Tl}_{0.5}\right)$ $(\mathrm{BaCa})(\mathrm{CaMg}) \mathrm{Cu}_{1} \mathrm{Zn}_{2} \mathrm{O}_{10-\delta},\left(\mathrm{Cu}_{0.5} \mathrm{TI}_{0.5}\right)(\mathrm{BaCa})(\mathrm{CaMg}) \mathrm{Zn}_{3} \mathrm{O}_{10-\delta}$ and $\left(\mathrm{A}_{\mathrm{y}} \mathrm{Tl}_{1-\mathrm{y}}\right)(\mathrm{BaCa})(\mathrm{CaMg}) \mathrm{Zn}_{3} \mathrm{O}_{10-\delta}(\mathrm{A}=\mathrm{Ag}, \mathrm{K}, \mathrm{Ni}, \mathrm{Mn} ; \mathrm{y}=0,0.5)$. Samples were prepared at normal pressure by using two-steps solid state reaction method. The characterization of samples is done via $\mathrm{x}$-ray diffraction (XRD), resistivity (RT) and Fourier Transform Infrared (FTIR) absorption measurements. Intrinsic superconducting parameters and activation energy of all sample is estimated applying two theoretical models, Fluctuation Induced conductivity (FIC) analysis and Mott 3D-VRH. The XRD and FTIR absorption measurements have confirmed the intrinsic doping of $\mathrm{K}, \mathrm{Ag}, \mathrm{Ni}, \mathrm{Mn}$ and $\mathrm{Zn}$. Interestingly, samples $\left(\mathrm{Cu}_{0.5} \mathrm{Tl}_{0.5}\right)(\mathrm{BaCa})(\mathrm{CaMg}) \mathrm{Zn}_{3} \mathrm{O}_{10-\delta}$ without $\mathrm{CuO}_{2}$ planes have exhibited superconducting behavior above $77 \mathrm{~K}$. To verify the role of $\mathrm{Cu}\left(3 \mathrm{~d}^{9}\right)$ atoms in superconductivity we have synthesized $\left(\mathrm{A}_{\mathrm{y}} \mathrm{TI} \mathrm{I}_{1-\mathrm{y}}\right)(\mathrm{BaCa})(\mathrm{CaMg}) \mathrm{Zn}_{3} \mathrm{O}_{10-\delta}(\mathrm{A}=\mathrm{Ag}, \mathrm{K}, \mathrm{Mn}, \mathrm{Ni} ; \mathrm{y}=0,0.5)$ samples. In aforementioned samples, doping of $\mathrm{Ni}, \mathrm{Mn}, \mathrm{K}, \mathrm{Ag}$ ions in $\mathrm{Cu}_{1-\mathrm{x}} \mathrm{Tl}_{\mathrm{x}} \mathrm{Ba}_{2} \mathrm{O}_{4-\delta}$ charge reservoir layer instead of Cu-atoms destroys the superconductivity completely and leads to semiconducting behavior. Key objective to preparing these samples is to investigate the role of two major parameters local moments (spin) of copper atoms and net carrier's concentration in superconductivity.

\section{Introduction}

In 1986 scientists found superconductivity in barium, lanthanum and copper oxide called $\mathrm{La}_{1.85} \mathrm{Ba}_{0.15} \mathrm{CuO}_{4}$. The breakthrough awarded the scientists a Nobel Prize in Superconductivity and triggered a surge in condensed-mater physics research. Although similar oxides have revealed superconductors at temperatures as low as $30 \mathrm{~K}, \mathrm{Tc}$ (transition temperatures) of later cuprates is almost an order of magnitude higher than any previously known superconductor [1-3]. In spite 33 years of research, no consent has arisen on causes of superconductivity in copper oxides [4-5]. As a result, main emphasis is on knowing the physical origin of the new Properties of the normal state in the expectation that these may provide significant insight into the advent of superconductivity at such high temperature. Cuprates are layered materials with a high anisotropy [6-7]. In oxides, superconductivity is found in $\mathrm{CuO}_{2}$ planes and these planes are connected with charge reservoir layers which are separated by $\mathrm{Ca}$ atoms. In the oxide superconductor, the charge reservoir layer(CRL) sends charges to the superconduting plane $\left(\mathrm{CuO}_{2}\right)$. The inter-plane coupling which is important in determining the magnitude of superconductivity arises from the correlation of carriers of different planes. The copper atoms in the $\mathrm{CuO}_{2}$ planes have a small paramagnetic spin, which interacts with the carriers in conducting bands. The magnetic moments of nearly filled $\mathrm{Cu}^{2+}\left(3 \mathrm{~d}^{9}\right)$ have strong antiferromagnetic interactions with neighboring spin-1/2 $\mathrm{Cu}$ ions and each $\mathrm{Cu}$ atom is bound by an $\mathrm{O}$ ion [8-10]. Chemical doping is often used to change the charge concentration in the $\mathrm{CuO}_{2}$ planes in order to explore the cuprate's unusual superconductivity. we will frame the discussion on two major parameters local moments( spin) and net carriers concentration. Here two questions arise. (1) Is there any contribution of spin of copper atoms $\left(3 \mathrm{~d}^{9}\right)$ ? (2)Which factors enhance spin-spin interaction ? In current study we have synthesize $\left(\mathrm{Cu}_{0.5} \mathrm{TI}_{0.5}\right)\left(\mathrm{Ba}_{2} \mathrm{Ca}_{2}\right) \mathrm{Cu}_{3} \mathrm{O}_{10-\delta}$ and Cu0.5TI0.5(BaCa)$(\mathrm{MgCa}) Z n y C u 3-y 010-\delta(\mathrm{y}=2,3)$ superconductors. In $\left(\mathrm{Cu}_{0.5} \mathrm{TI}_{0.5}\right)(\mathrm{BaCa})$ $(\mathrm{CaMg}) \mathrm{Zn}_{3} \mathrm{O}_{10-\delta}$ sample we witnessed superconducting behavior even though $\mathrm{Zn}$ atoms, non-spin carrying entity with $3 \mathrm{~d}^{10}$ state and mass almost equal to the Copper atom completely replace Cu-atoms in $\mathrm{CuO}_{2}$ planar sites and make $\mathrm{ZnO}_{2}$ plane. In the aforementioned sample superconductivity suppresses but it does not disappear, this trend arise a question and that is there any role of spin atom essential for the mechanism of superconductivity. To investigate the role of spin we replace spin carrying copper atom in charge reservoir layer $\mathrm{Cu}_{0.5} \mathrm{TI}_{0.5}(\mathrm{BaCa}) \mathrm{O}_{4-\delta}$, by thallium atoms and synthesize $\left(\mathrm{TI}_{1.0}\right)(\mathrm{BaCa})(\mathrm{CaMg}) \mathrm{Zn}_{3} \mathrm{O}_{10-\delta}$ sample in which copper $\mathrm{Cu}\left(3 \mathrm{~d}^{9}\right)$ atom is transformed from $\mathrm{CRL} \mathrm{TI} 1.0(\mathrm{BaCa}) \mathrm{O}_{4-\delta}$. Surprisingly sample turn semiconductor altogether. This result raised many questions.

To answer such questions and to investigate the role of local moments of impurity atoms (spins of copper) and net carriers concentration. We prepared samples by doping the charge reservoir layer with transition metals noble and Alkali metals.

Our technique for getting more knowledge is to replace copper atom $\mathrm{Cu}\left(3 \mathrm{~d}^{9}\right)$ by others transition metal ions. In periodic table Nickle sit next to copper atom. So We synthesize $\left(\mathrm{Ni}_{0.5} \mathrm{TI}_{0.5}\right)(\mathrm{BaCa})(\mathrm{CaMg}) \mathrm{Zn}_{3} \mathrm{O}_{10-\delta}$ by replacing Copper atoms in charge reservoir layers $\mathrm{Cu}_{0.5} \mathrm{Tl}_{0.5}(\mathrm{BaCa}) \mathrm{O}_{4-\delta}$ by transition metals ions $\mathrm{Ni}\left(3 \mathrm{~d}^{8}\right)$ substitution in the charge reservoir layer(CRL) again sample revealed semiconducting properties.

This arised other questions to be answered that is there any role of increase or decrease in effective magnetic moment per lattice site that disturbed the superconductivity?. In this scenario, we further prepared two samples $\left(\mathrm{Mn}_{0.5} \mathrm{TI}_{0.5}\right)(\mathrm{BaCa})(\mathrm{CaMg}) \mathrm{Zn}_{3} \mathrm{O}_{10-\delta}$ and $\left(\mathrm{AgO} 0.5 \mathrm{TI}_{0.5}\right)$ $(\mathrm{BaCa})(\mathrm{CaMg}) \mathrm{Zn}_{3} \mathrm{O}_{10-\delta}$ by replacing Copper atoms in charge reservoir layers $\mathrm{Cu}_{0.5} \mathrm{Tl}_{0.5}(\mathrm{BaCa}) \mathrm{O}_{4-\delta}$ by transition metals ions $\mathrm{Mn}\left(3 \mathrm{~d}^{5}\right)$ Loading [MathJax]/jax/output/CommonHTML/jax.js 
and Nobel Metal Ag. Astonishing no superconductivity was observed in such samples and it confirmed from results, superconductivity is only maintained in copper doped samples whereas doping with various d-Block elements ( $\mathrm{Tl}, \mathrm{Ni}, \mathrm{Mn}, \mathrm{Ag}$ ) show semiconducting behavior.

Role of carrier concentration cannot be ruled out to study superconducting behavior. The copper atoms that are only present in $\mathrm{CuO}_{2}$ planes are deficient in carriers and their spins are aligned antiferromagnetically, while charge reservoir layers have high carriers density. In order to enhance the density of charge carrier we prepared $\left(\mathrm{K}_{0.5} \mathrm{TI}_{0.5}\right)(\mathrm{BaCa})(\mathrm{CaMg}) \mathrm{Zn}_{3} \mathrm{O}_{10-\delta}$ sample by replacing charge reservoir layers $\mathrm{Cu}_{0.5} \mathrm{TI}_{0.5}(\mathrm{BaCa}) \mathrm{O}_{4-\delta}$ by this $\mathrm{K}_{0.5} \mathrm{TI}_{0.5}(\mathrm{BaCa}) \mathrm{O}_{4-\delta}$ by substituting Potassium $\mathrm{K}$ on Copper sites. These samples with Alkali and Nobels metals also exhibited semiconducting variation of resistivity following Variable Range Hopping conductivity.

\section{Experiment}

These samples $\left(\mathrm{Cu}_{0.5} \mathrm{Tl}_{0.5}\right) \mathrm{Ba}_{2} \mathrm{Ca}_{2} \mathrm{Cu}_{3} \mathrm{O}_{10-\delta}\left(\mathrm{Cu}_{0.5} \mathrm{TI}_{0.5}\right)(\mathrm{BaCa})(\mathrm{CaMg}) \mathrm{Cu}_{1} \mathrm{Zn}_{2} \mathrm{O}_{10-\delta}$ and $\left(\mathrm{Cu}_{0.5} \mathrm{Tl}_{0.5}\right)(\mathrm{BaCa})(\mathrm{CaMg}) \mathrm{Zn}_{3} \mathrm{O}_{10-\delta}$ were prepared from solid state reaction technique completed in two stages using $\mathrm{Ca}\left(\mathrm{NO}_{3}\right)_{2}+4 \mathrm{H}_{2} \mathrm{O}, \mathrm{MgO}, \mathrm{Ba}\left(\mathrm{NO}_{3}\right)_{2}, \mathrm{Cu}_{2}(\mathrm{CN})_{2}+\mathrm{H}_{2} \mathrm{O}$, ZnO. we also synthesized $\left(\mathrm{A}_{\mathrm{y}} \mathrm{TI}_{1-\mathrm{y}}\right)(\mathrm{BaCa})(\mathrm{CaMg}) \mathrm{Zn}_{3} \mathrm{O}_{10-\delta}(\mathrm{A}=\mathrm{Ag}, \mathrm{K}, \mathrm{Ni}, \mathrm{Mn} ; \mathrm{y}=0,0.5)$ sample by two steps SSR method using $\mathrm{Ca}\left(\mathrm{NO}_{3}\right)_{2}+4 \mathrm{H}_{2} \mathrm{O}, \mathrm{MgO}$, $\mathrm{Ba}\left(\mathrm{NO}_{3}\right)_{2}, \mathrm{ZnO}, \mathrm{Ni}\left(\mathrm{NO}_{3}\right)_{2}+\mathrm{H}_{2} \mathrm{O}, \mathrm{MnO}_{2}, \mathrm{AgNO}_{3}, \mathrm{~K}_{2} \mathrm{CO}_{3}$ materials. Appropriate quantities of all high purity compounds is mixed, ground and sintered at $860^{\circ} \mathrm{C}$ for 24 hours in a quartz boat with another intermediate grinding. Now in the twice fired material measured amount of $\mathrm{Tl}_{2} \mathrm{O}_{3}$ is mixed to get required compounds. The pressure of $3.8 \mathrm{tons} / \mathrm{cm}^{2}$ is being used to pelletize these powder compounds. To reduce $\mathrm{TI}$ losses, these pellets were individually wrapped in gold capsules and sintered at $860^{\circ} \mathrm{C}$ for 10 minutes before being cooled to room temperature. X-ray diffraction was used to identify the material's crystal structure (XRD). The resistivity-temperature measurement is carried using four-probe method. (FTIR) Fourier Transform Infrared Spectroscopy measurements were used at ambient temperature to investigate phonon's modes.

\section{Discussion And Results}

Fig. 1(a) and Fig. 1(b) shows the X-ray spectra of $\left(\mathrm{Cu}_{0.5} \mathrm{TI}_{0.5}\right) \mathrm{Ba}_{2} \mathrm{Ca}_{2} \mathrm{Cu}_{3} \mathrm{O}_{10-\delta},\left(\mathrm{Cu}_{0.5} \mathrm{Tl}_{0.5}\right)(\mathrm{BaCa})(\mathrm{CaMg}) \mathrm{Cu}_{1} \mathrm{Zn}_{2} \mathrm{O}_{10-\delta},\left(\mathrm{Cu}_{0.5} \mathrm{Tl}_{0.5}\right)(\mathrm{BaCa})$ $(\mathrm{CaMg}) \mathrm{Zn}_{3} \mathrm{O}_{10-\delta}$ and $\left(\mathrm{A}_{\mathrm{y}} \mathrm{TI}_{1-\mathrm{y}}\right)(\mathrm{BaCa})(\mathrm{CaMg}) \mathrm{Zn}_{3} \mathrm{O}_{10-\delta}(\mathrm{A}=\mathrm{Ag}, \mathrm{K}, \mathrm{Ni}, \mathrm{Mn} ; \mathrm{y}=0,0.5)$ samples. The planar reflection of these samples corresponds to an orthorhombic crystal structure possessing Pmmm as space group. $\mathrm{BaCuO}_{2}$ has a smaller number of impurity peaks, which has been revealed in diffraction scan. $\mathrm{BaCuO}_{2}$ is a well-known stable chemical. It is produced by the decomposition of starting compounds through the decomposition of $\mathrm{Ba}\left(\mathrm{NO}_{3}\right)_{2}$ at early stages. The decomposed temperature of $\mathrm{Ba}\left(\mathrm{CuO}_{2}\right)$ is greater than thermally stable temperature of samples $\left(\sim 860^{\circ} \mathrm{C}\right)$, thus it stays in final compound's integral part. The variation of a and c-axis length is attributed to the fact that the ionic radius of TI ions (1.48 A) is slightly greater than $\mathrm{Cu}, \mathrm{Ag} \mathrm{Mn}$ ions [11] shown in Table 1. In CuTI-1223 low intensity impurity peaks are detected in diffractogram. Structural changes can be seen in the final compound due to presence of different ionic radii.

Table 1

Shows the a-axis, b-axis, c-axis and volume values calculated from XRD analysis of $\mathrm{Cu}_{0.5} \mathrm{TI}_{0.5} \mathrm{Ba}_{2} \mathrm{Ca}_{2} \mathrm{Cu}_{3} \mathrm{O}_{10-\delta}$ and $\mathrm{Cu}_{0.5} \mathrm{Tl}_{0.5}(\mathrm{BaCa})$ $(\mathrm{MgCa}) \mathrm{Zn}_{\mathrm{y}} \mathrm{Cu}_{3-\mathrm{y}} \mathrm{O}_{10-\delta}(\mathrm{y}=2,3)$ superconductors and of $\left(\mathrm{A}_{\mathrm{y}} \mathrm{TI}_{1-\mathrm{y}}\right)(\mathrm{BaCa})(\mathrm{CaMg}) \mathrm{Zn}_{3} \mathrm{O}_{10-\delta}(\mathrm{A}=\mathrm{Ag}, \mathrm{K}, \mathrm{Ni}, \mathrm{Mn} ; \mathrm{y}=0,0.5)$ samples

\begin{tabular}{|c|c|c|c|c|c|}
\hline $\mathbf{S} / \mathbf{N}$ & Sample & a-axis $(\AA)$ & b-axis $(\AA)$ & c-axis $(\AA)$ & Volume $\left(A^{3}\right)$ \\
\hline $\mathrm{Cu}_{0.5} \mathrm{TI}_{0.5} \mathrm{Ba}_{2} \mathrm{Ca}_{2} \mathrm{Cu}_{3} \mathrm{O}_{10-\delta}$ & 3.83 & 3.81 & 14.44 & 207 & \\
\hline $\mathrm{Cu}_{0.5} \mathrm{TI}_{0.5}(\mathrm{BaCa})(\mathrm{MgCa}) \mathrm{Zn}_{2} \mathrm{Cu}_{1} \mathrm{O}_{10-\delta}$ & 3.84 & 3.82 & 14.57 & 213 & \\
\hline 3 & $\mathrm{Cu}_{0.5} \mathrm{TI}_{0.5}(\mathrm{BaCa})(\mathrm{MgCa}) \mathrm{Zn}_{3.0} \mathrm{O}_{10-\delta}$ & 3.96 & 3.91 & 14.83 & 225 \\
\hline 4 & $\mathrm{TI}_{1.0}(\mathrm{BaCa})(\mathrm{MgCa}) \mathrm{Zn}_{3.0} \mathrm{O}_{10-\delta}$ & 3.50 & 3.82 & 14.11 & 188 \\
\hline 5 & $\mathrm{~K}_{0.5} \mathrm{Tl}_{0.5}(\mathrm{BaCa})(\mathrm{MgCa}) \mathrm{Zn}_{3.0} \mathrm{O}_{10-\delta}$ & 3.72 & 3.83 & 14.04 & 198 \\
\hline 6 & $\mathrm{Ag}_{0.5} \mathrm{TI}_{0.5}(\mathrm{BaCa})(\mathrm{MgCa}) \mathrm{Zn}_{3.0} \mathrm{O}_{10-\delta}$ & 3.70 & 3.74 & 14.03 & 196 \\
\hline 7 & $\mathrm{Ni}_{0.5} \mathrm{TI}_{0.5}(\mathrm{BaCa})(\mathrm{MgCa}) \mathrm{Zn}_{3.0} \mathrm{O}_{10-\delta}$ & 3.71 & 3.77 & 14.10 & 200 \\
\hline 8 & $\mathrm{Mn}_{0.5} \mathrm{Tl}_{0.5}(\mathrm{BaCa})(\mathrm{MgCa}) \mathrm{Zn}_{3.0} \mathrm{O}_{10-\delta}$ & 3.69 & 3.70 & 14.07 & 197 \\
\hline
\end{tabular}

Loading [MathJax]/jax/output/CommonHTML/jax.js 
Fig. 2(a) show temperature dependence of resistivity plots of $\left(\mathrm{Cu}_{0.5} \mathrm{Tl}_{0.5}\right) \mathrm{Ba}_{2} \mathrm{Ca}_{2} \mathrm{Cu}_{3} \mathrm{O}_{10-\delta \text {, }}\left(\mathrm{Cu}_{0.5} \mathrm{Tl}_{0.5}\right)(\mathrm{BaCa})(\mathrm{CaMg}) \mathrm{Cu}_{1} \mathrm{Zn}_{2} \mathrm{O}_{10-\delta}$ and $\left(\mathrm{Cu}_{0.5} \mathrm{TI}_{0.5}\right)(\mathrm{BaCa})(\mathrm{CaMg}) \mathrm{Zn}_{3} \mathrm{O}_{10-\delta}$ samples. These samples exhibited superconducting metallic variations of resistivity from room temperature down to $(R=0)$ and have Tc around 100.2, 92 and $91 \mathrm{~K}$, Tc (onset) 113,108,119 $\mathrm{K}$ respectively shown in Table 2. As demonstrated in Fig. 2(b,c,d,e,f), all samples $\left(\mathrm{A}_{\mathrm{y}} \mathrm{Tl} \mathrm{I}_{1-\mathrm{y}}\right)(\mathrm{BaCa})(\mathrm{CaMg}) \mathrm{Zn}_{3} \mathrm{O}_{10-\delta}(\mathrm{A}=\mathrm{Ag}, \mathrm{K}, \mathrm{Ni}, \mathrm{Mn} ; \mathrm{y}=0,0.5)$ have semiconductor-like resistivity variations with temperature.

Table 2

Shows the parameters $T_{c}[$ [onset $]$ and $T_{C}[R=0]$ calculated from resistivity

vs. temperature graphs of $\mathrm{Cu}_{0.5} \mathrm{Tl}_{0.5} \mathrm{Ba}_{2} \mathrm{Ca}_{2} \mathrm{Cu}_{3} \mathrm{O}_{10-\delta}$ and

$\mathrm{Cu}_{0.5} \mathrm{TI}_{0.5}(\mathrm{BaCa})(\mathrm{MgCa}) \mathrm{Zn}_{\mathrm{y}} \mathrm{Cu}_{3-\mathrm{y}} \mathrm{O}_{10-\delta}(\mathrm{y}=2,3)$ superconductors.

\begin{tabular}{|lll|}
\hline Sample & $\mathrm{T}_{\mathrm{c}}[\mathrm{R}=0](\mathrm{K})$ & $\mathrm{T}_{\mathrm{c}}$ [onset] (K) \\
\hline $\mathrm{Cu}_{0.5} \mathrm{TI}_{0.5} \mathrm{Ba}_{2} \mathrm{Ca}_{2} \mathrm{Cu}_{3} \mathrm{O}_{10-\delta}$ & 100.2 & 113 \\
$\mathrm{Cu}_{0.5} \mathrm{TI}_{0.5}(\mathrm{BaCa})(\mathrm{MgCa}) \mathrm{Zn}_{2} \mathrm{Cu}_{1} \mathrm{O}_{10-\delta}$ & 92 & 108 \\
$\mathrm{Cu}_{0.5} \mathrm{TI}_{0.5}(\mathrm{BaCa})(\mathrm{MgCa}) \mathrm{Zn}_{3.0} \mathrm{O}_{10-\delta}$ & 91 & 119 \\
\hline
\end{tabular}

Various models have been used to characterize electrical properties; the conduction process is guided by charge carriers hopping between levels via different methods. In many disordered carbon forms for charge carriers the Mott variable range hopping (VRH) and thermally assisted hopping are suggested as probable conduction mechanisms [12-13]. Eqn (1) gives the Mott VRH model, which is based on charge carriers hopping between localized states near the Fermi level with the assist of thermal energy. To is the characteristic hopping temperature while factor $\left(\rho_{0}\right)$ is temperature T dependent.

$$
\rho(T)=\rho_{o} \exp \left[\left(\frac{T_{o}}{T}\right)^{1 / 4}\right]
$$

Due to the randomization in the conduction channels, carrier transport is actually proceeds via three-dimensional (3D) variable range hopping process. As a result using the Mott 3D VRH type conduction mechanism (equation (1), b =1/4) [14-15] the $\rho-T$ data of the various samples was evaluated. The Mott 3D VRH model remains in good fit for the experimental data of our samples. All samples $\left.\left(\mathrm{A}_{\mathrm{y}} \mathrm{Tl}_{1-\mathrm{y}}\right)(\mathrm{BaCa})(\mathrm{CaMg}) \mathrm{Zn}_{3} \mathrm{O}_{10-\delta}(\mathrm{A}=\mathrm{Ag}, \mathrm{K}, \mathrm{Ni}, \mathrm{Mn} ; \mathrm{y}=0,0.5)\right)$ have semiconductor-like resistivity variations with temperature fitted by equation 1 in the temperature regime from 77K to 300K shown in Fig. 3(a,b,c,d,e). The inset represents the plot of In $\mid$ varvec $\rho$ vs. 1/T ${ }^{1 / 4}$, where the theoretical prediction for the Mott Varying Range Hopping (VRH) in 3D mechanism is indicated by the straight line. The energy of activation for $\mathrm{Tl}_{1.0}(\mathrm{BaCa})(\mathrm{CaMg}) \mathrm{Zn}_{3} \mathrm{O}_{10-\delta}, \mathrm{Tl}_{0.5} \mathrm{Ag}_{0.5}(\mathrm{BaCa})(\mathrm{CaMg}) \mathrm{Zn}_{3} \mathrm{O}_{10-\delta}, \mathrm{Tl}_{0.5} \mathrm{~K}_{0.5}(\mathrm{BaCa})(\mathrm{CaMg}) \mathrm{Zn}_{3} \mathrm{O}_{10-\delta}, \mathrm{Tl}_{0.5} \mathrm{Ni}_{0.5}(\mathrm{BaCa})$ $(\mathrm{CaMg}) \mathrm{Zn}_{3} \mathrm{O}_{10-\delta}$, and $\mathrm{TI}_{0.5} \mathrm{Mn}_{0.5}(\mathrm{BaCa})(\mathrm{CaMg}) \mathrm{Zn}_{3} \mathrm{O}_{10-\delta}$, sample is $1.85 \mathrm{meV}, 1.41 \mathrm{meV}, 2.35 \mathrm{meV}, 2.34 \mathrm{meV}$ and $6.89 \mathrm{meV}$ respectively as shown in Table 3.

Table 3

Activation energy of $\left(\mathrm{A}_{\mathrm{y}} \mathrm{Tl}_{1-\mathrm{y}}\right)(\mathrm{BaCa})(\mathrm{CaMg}) \mathrm{Zn}_{3} \mathrm{O}_{10-\delta}(\mathrm{A}=\mathrm{Ag}$,

$\mathrm{K}, \mathrm{Ni}, \mathrm{Mn} ; \mathrm{y}=0,0.5)$ samples

\begin{tabular}{|ll|}
\hline Sample & $\begin{array}{l}\text { Activation Energy } \\
\mathrm{Ea}(\mathrm{meV})\end{array}$ \\
\hline $\mathrm{K}_{0.5} \mathrm{Tl}_{0.5}(\mathrm{BaCa})(\mathrm{MgCa}) \mathrm{Zn}_{3.0} \mathrm{O}_{10-\delta}$ & 2.35 \\
\hline $\mathrm{Ag}_{0.5} \mathrm{Tl}_{0.5}(\mathrm{BaCa})(\mathrm{MgCa}) \mathrm{Zn}_{3.0} \mathrm{O}_{10-} \delta$ & 1.41 \\
\hline $\mathrm{TI}_{1.0}(\mathrm{BaCa})(\mathrm{MgCa}) \mathrm{Zn}_{3.0} \mathrm{O}_{10-}$ & 1.85 \\
\hline $\mathrm{Mn}_{0.5} \mathrm{TI}_{0.5}(\mathrm{BaCa})(\mathrm{MgCa}) \mathrm{Zn}_{3.0} \mathrm{O}_{10-\delta}$ & 6.89 \\
\hline $\mathrm{Ni}_{0.5} \mathrm{Tl}_{0.5}(\mathrm{BaCa})(\mathrm{MgCa}) \mathrm{Zn}_{3.0} \mathrm{O}_{10-\delta}$ & 2.34 \\
\hline
\end{tabular}

We observed superconductivity in $\left(\mathrm{Cu}_{0.5} \mathrm{TI}_{0.5}\right)(\mathrm{BaCa})(\mathrm{CaMg}) \mathrm{Zn}_{3} \mathrm{O}_{10-} \delta$ sample without $\mathrm{CuO}_{2}$ plane. As we know charge reservoir layer $\mathrm{Cu}_{0.5} \mathrm{TI}_{0.5}(\mathrm{BaCa}) \mathrm{O}_{4-\delta}$ supply carriers to the superconducting planes $\mathrm{CuO}_{2}$ plane as $\mathrm{Cu}$-atom from $\mathrm{CRL}$ jump to $\mathrm{ZnO}_{2}$ planar sites and their presence both in Superconductina plane and charge reservoir layer produce spin fluctuation and disturb Anti-ferromagnetic order. In order Loading [MathJax]/jax/output/CommonHTML/jax.js

Page $4 / 11$ 
to verify the role of copper spin $\left(3 d^{9}\right)$ we prepared $\left(A_{y} T_{1-y}\right)(B a C a)(C a M g) Z_{3} O_{10-\delta}(A=N i, M n, A g, K ; y=0,0.5)$ samples, main objective to prepare these samples is to completely remove copper from the charge reservoir layer $\mathrm{Cu}_{0.5} \mathrm{TI}_{0.5}(\mathrm{BaCa}) \mathrm{O}_{4-\delta}$ and superconducting planes $\mathrm{CuO}_{2}$. In such samples Cu-based CRL is exchanged by $\mathrm{Tl}_{1.0}(\mathrm{BaCa}) \mathrm{O}_{4-\delta}, \mathrm{Ni}_{0.5} \mathrm{TI}_{0.5}(\mathrm{BaCa}) \mathrm{O}_{4-\delta}, \mathrm{Mn}_{0.5} \mathrm{Tl}_{0.5}(\mathrm{BaCa}) \mathrm{O}_{4-\delta}, \mathrm{Ag}_{0.5} \mathrm{TI}_{0.5}(\mathrm{BaCa}) \mathrm{O}_{4-\delta}$ and $\mathrm{K}_{0.5} \mathrm{Tl}_{0.5}(\mathrm{BaCa}) \mathrm{O}_{4-\delta}$. As all $\mathrm{CRL}$ layers are conducting, none of them possess a spin-carrying particle like $\mathrm{Cu}\left(3 \mathrm{~d}^{9}\right)$. As a result, such charge reservoir layers eliminate the possibility of $\mathrm{Cu}$-atoms diffusing to $\mathrm{CuO}_{2}$-planar positions. As a result, all samples without copper atoms in the CRL have exhibited semiconducting conductivity with different activation energy.

As copper $\mathrm{Cu}\left(3 \mathrm{~d}^{9}\right)$ is transitional metal, we replace copper atoms from $C R L$ by another d-element nickel $\mathrm{Ni}\left(3 \mathrm{~d}^{8}\right)$ that is ferromagnetic entity [16] that can supply alternatively larger spin as compared to $\mathrm{Cu}\left(3 \mathrm{~d}^{9}\right)$ atoms of $\mathrm{CRL} \mathrm{Cu}_{0.5} \mathrm{TI}_{0.5}(\mathrm{BaCa}) \mathrm{O}_{4-\delta}$. $\ln \left(\mathrm{Ni}_{0.5} \mathrm{TI}_{0.5}\right)(\mathrm{BaCa})$ (CaMg) $\mathrm{Zn}_{3} \mathrm{O}_{10}$ - sample we increase interplanar coupling by doping $\mathrm{Mg}$ atoms at Calcium sites and in $\mathrm{CRL} \mathrm{Cu}_{0.5} \mathrm{Tl}_{0.5}(\mathrm{BaCa}) \mathrm{O}_{4-\delta}$ replace copper atoms with $\mathrm{Ni}\left(3 \mathrm{~d}^{8}\right)$. Results have shown that with Ni-doping we obtain semiconducting behavior. Now we prepare another sample $\left(\mathrm{Mn}_{0.5} \mathrm{TI}_{0.5}\right)(\mathrm{BaCa})(\mathrm{CaMg}) \mathrm{Zn}_{3} \mathrm{O}_{10-} \delta$ by doping d-element $\mathrm{Mn}\left(3 \mathrm{~d}^{6}\right)$ in charge reservoir layer. To enhance magnetic moment per lattice cell we substitute $\mathrm{Mn}$ in charge reservoir layer (CRL) $\mathrm{Mn}_{0.5} \mathrm{TI}_{0.5}(\mathrm{BaCa}) \mathrm{O}_{4-\delta}$. As superconducting planes are deficient of carriers and there is antiferromagnetic alignment of spin when $\mathrm{Mn}$ is substituted in (CRL) $\mathrm{Mn}_{0.5} \mathrm{Tl}_{0.5}(\mathrm{BaCa}) \mathrm{O}_{4-\delta}$ it induce no superconducting transition and the sample obeyed semiconducting behavior. $\mathrm{Mn}$ is a magnetic impurity that causes pairs breaking; hence no superconductivity might be expected.

We synthesize further sample $\left(\mathrm{Ag}_{0.5} \mathrm{TI}_{0.5}\right)(\mathrm{BaCa})(\mathrm{CaMg}) \mathrm{Zn}_{3} \mathrm{O}_{10-\delta}$ by doping $\mathrm{Ag}\left(4 \mathrm{~d}^{10}\right)$ in $\mathrm{CRL} \mathrm{Ag}_{0.5} \mathrm{Tl}_{0.5}(\mathrm{BaCa}) \mathrm{O}_{4-\delta}$ plane. The idea to doped Nobel metal instead of $\mathrm{Cu}\left(3 \mathrm{~d}^{9}\right)$ to check is there any significance of spin carrying entity in the mechanism of superconductivity at high temperature? Such samples have shown semiconducting behavior.

To investigate the role of the density of charge carrier we synthesize $\left(\mathrm{K}_{0.5} \mathrm{Tl}_{0.5}\right)(\mathrm{BaCa})(\mathrm{CaMg}) \mathrm{Zn}_{3} \mathrm{O}_{10-\delta}$ using Alkali Metal so potassium $\mathrm{K}\left(4 \mathrm{~s}^{1}\right)$ is introduced in charge reservoir layer. $\mathrm{K}$ is substituted in $\mathrm{CRL} \mathrm{K} \mathrm{K}_{0.5} \mathrm{TI}_{0.5}(\mathrm{BaCa}) \mathrm{O}_{4-\delta}$ to increase density of charge carriers in superconducting plane $\mathrm{Cu} / \mathrm{ZnO}_{2}$. Even the deliberate enhancement in the carrier density Via K-doping at charge reservoir layer sites have not given us superconductivity down to $77 \mathrm{~K}$ instead produce semiconducting samples.

All such studies have revealed some of $\mathrm{Cu}$-atoms in the $\mathrm{CRL} \mathrm{Cu} 0.5 \mathrm{Tl}_{0.5}(\mathrm{BaCa}) \mathrm{O}_{4-\delta}$ most likely hop to the $\mathrm{ZnO}_{2}$ planes. This shows the significance of spin carrying $\mathrm{Cu}\left(3 \mathrm{~d}^{9}\right)$ atoms in the plane that cause fluctuating in spin and produce spin density wave. These spin fluctuation seem to mediate long range phase coherence established superconductivity at Tc. In cuprates spin of copper atom play vital role in superconductivity. While all samples $\left(\mathrm{A}_{\mathrm{y}} \mathrm{TI}_{1-\mathrm{y}}\right)(\mathrm{BaCa})(\mathrm{CaMg}) \mathrm{Zn}_{3} \mathrm{O}_{10-\delta}(\mathrm{A}=\mathrm{Ag}, \mathrm{K}, \mathrm{Ni}, \mathrm{Mn} ; \mathrm{y}=0,0.5)$ without Copper atoms show semiconducting behavior which supports our thesis that in the absence of a copper atom, electron spins flip on varying degree that causes scattering waves asymmetrically that in turn disturb coherence in wave function. This process disrupts phase coherence, resulting in destructive interference, which leads to an increase in resistivity [17-19].

Conventional superconductors possess $s$-wave symmetry and are isotropic. Cooper pairing of electrons is mediated by lattice phonons. While in cuprates the superconducting wavefunction possesses d-wave symmetry, which means it changes sign when rotated by $90^{\circ}$ [2021 ]. When a cuprate is doped, the charge carriers delocalize due to hybridization between the Cu (3d) and O (2p) orbitals. Still, it's unclear what causes the material to superconductor at some critical doping levels. The pairing mechanism may be initiated by superexchange phenomena, in which spin fluctuations between neighboring $\mathrm{Cu}$ sites are mediated by $\mathrm{O}$ atoms that partition the $\mathrm{Cu}$ atoms. The $\mathrm{Cu}\left(\mathrm{d}_{\mathrm{x}}{ }^{2}-\mathrm{y}\right.$ ${ }^{2}$ ) orbital's energy is almost degenerate with those of $\mathrm{O}(2 \mathrm{p})$ orbitals in cuprates, making hybridization and hence spin fluctuation extremely strong. The energy levels of the $\mathrm{Ni}, \mathrm{Ag}, \mathrm{K}, \mathrm{Mn}$, and $\mathrm{O}$ orbitals, on the other hand, are quite different, weakening the spin fluctuations [22-23].

Aslamazov and Larkin [24] used a microscopic technique to calculate excess conductivity where the fluctuation are modest. They derived $\sigma / \sigma 300=A \varepsilon^{\lambda}(1)$ with reduced temperature $\varepsilon=(T-T \mathrm{mf}) / T \mathrm{mf}$ ( mean field temperature $T \mathrm{mf}$ is calculated from peak of $\mathrm{d} \rho / \mathrm{d} T$ against $T$ plot). The Lawrence and Doniach (LD) model for the polycrystalline samples, is as follow [25].

$\Delta \sigma_{\mathrm{LD}}=\left[\mathrm{e}^{2} /(16 \hbar d)\right]\left(1+\mathrm{J} \varepsilon^{-1}\right)^{-1 / 2} \varepsilon^{-1}(2)$

In the preceding expression $\mathrm{J}=\left[2 \xi_{\mathrm{c}(0)} / \mathrm{d}\right]^{2}$ represent inter-CuO $\mathrm{C}_{2}$-layers couplings, $\mathrm{d}$ signifies thickness of superconducting layers and the coherence length $\xi_{c(0)}$ is along c-axis. By using LD model the coherence length is determined from the crossover temperatures by

Loading [MathJax]/jax/output/CommonHTML/jax.js ples [26]. 
$\xi_{c(0)}=d / 2\left[\left(T_{3 D-2 D} / T_{m f}\right)-1\right]^{1 / 2}(3)$

$\ln (\sigma)$ was plotted against $\ln (\varepsilon)$ in Fig. $4(\mathrm{a}, \mathrm{b}, \mathrm{c})$ to analyze the excess conductivity applying AL model. This can be seen, each plot is categorized into three distinct regions. The different sections of the plots are linearly fitted and exponent values ' $\lambda$ ' is derived from the slopes to relate the experimental results with theoretical values. The $\lambda c r$ (critical exponent) corresponds to the critical region has a value of $0.33, \lambda_{3 D}$ values ranging from -0.48 to -0.564 showing $3 \mathrm{D}$ behavior, $\lambda_{2 D}$ values ranging -0.92 to -1.0089 signifying $2 \mathrm{D}$ behavior see in Table 4. In afore mentioned samples Mg-atoms are substituted at $\mathrm{Ca}$ sites, in prior research $\mathrm{Ca}$ by $\mathrm{Mg}$ atoms were successfully replaced, that suppresses c-axis length and rise critical current density [27]. The critical temperature does not rise in $\left(\mathrm{Cu}_{0.5} \mathrm{Tl}_{0.5}\right)(\mathrm{BaCa})(\mathrm{CaMg})$ $\left(\mathrm{Cu}_{3-\mathrm{x}} \mathrm{Zn}_{\mathrm{x}}\right) \mathrm{O}_{10-\mathrm{d}}(\mathrm{x}=2,3)$ samples indicating that the $\mathrm{Zn}\left(3 \mathrm{~d}^{10}\right)$ cause disorder in antiferromagnetic aligned of copper atoms $\left(3 \mathrm{~d}^{9}\right)$ spins within $\mathrm{CuO}_{2}$ plane. Because of disturbance in the spin density waves (SDW) charge stripes are likely to reorder, lead to suppressing superconductivity.

Table 4

Shows widths of critical, 3D, 2D, and OD fluctuation regions observed from

\begin{tabular}{|lllllllllll|}
\hline Sample & $\lambda_{\mathrm{CR}}$ & $\lambda_{3 \mathrm{D}}$ & $\lambda_{2 \mathrm{D}}$ & $\lambda_{\text {OD }}$ & $\begin{array}{l}\mathrm{T}_{\mathrm{CR}-3 \mathrm{D}}=\mathrm{T}_{\mathrm{G}} \\
(\mathrm{K})\end{array}$ & $\begin{array}{l}\mathrm{T}_{3 \mathrm{D}-2 \mathrm{D}} \\
(\mathrm{K})\end{array}$ & $\begin{array}{l}\mathrm{T}_{2 \mathrm{D}-\mathrm{OD}} \\
(\mathrm{K})\end{array}$ & $\mathrm{T}_{\mathrm{C}}{ }^{\mathrm{mf}}(\mathrm{K})$ & $\begin{array}{l}\mathrm{T}^{*} \\
(\mathrm{~K})\end{array}$ & $\begin{array}{l}\mathrm{a}=\rho_{\mathrm{n}}(\mathrm{OK}) \\
(\Omega-\mathrm{Cm})\end{array}$ \\
\hline $\mathrm{y}=0$ & 0.30 & 0.53 & 1.0 & 2.0 & 106 & 109 & 112 & 101.8 & 136 & 0.45 \\
$\mathrm{y}=2$ & 0.33 & 0.5 & 1.2 & 2.0 & 102.5 & 105 & 110 & 97.5 & 129 & 0.40 \\
$\mathrm{y}=3.0$ & 0.32 & 0.51 & 1.1 & 2.0 & 104 & 108 & 112 & 100.2 & 140 & 2.1 \\
\hline
\end{tabular}

We elucidated important superconducting parameters using Ginzburg Landau theory and equation stated in our earlier articles [28-30]. The parameters like $\mathrm{J}_{\mathrm{c}}(0), \mathrm{B}_{\mathrm{c}(0)}, \mathrm{B}_{\mathrm{c} 1(0)}, \mathrm{B}_{\mathrm{c} 2(0)}$, and $\mathrm{K}=\lambda / \xi$ are computed for $\left(\mathrm{Cu}_{0.5} \mathrm{Tl}_{0.5}\right) \mathrm{Ba}_{2} \mathrm{Ca}_{2} \mathrm{Cu}_{3} \mathrm{O}_{10-\delta}$ and $\left(\mathrm{Cu}_{0.5} \mathrm{Tl}_{0.5}\right)(\mathrm{BaCa})(\mathrm{CaMg})$ $\left(\mathrm{Cu}_{3-\mathrm{x}} \mathrm{Zn}_{\mathrm{x}}\right) \mathrm{O}_{10-\delta}(\mathrm{x}=2,3)$ samples, shown in Table 5 . In our samples the values of $J_{c}(0), B_{c 0}(T)$, $B_{c 1}(T)$ suppressed. The number of unintended defects, calculated by parameter a in samples enhanced with increasing Zn-doping, decrease in $B_{c(0)}, B_{c 1(0)}, B_{c 2(0)}, J_{c}(0)$ values indicate that these defects are not behaving as pinning centers. Table 5 shows that the London penetration depth $\lambda_{\mathrm{p} . d}$ and the GL parameter increase in all doped samples.

Table 5

Shows the superconductivity parameters observed from the FIC analysis of $\mathrm{Cu}_{0.5} \mathrm{Tl}_{0.5} \mathrm{Ba}_{2} \mathrm{Ca}_{2} \mathrm{Cu}_{3} \mathrm{O}_{10-\delta}$ and $\mathrm{Cu}_{0 \cdot 5} \mathrm{TI}_{0.5}(\mathrm{BaCa})$ $(\mathrm{MgCa}) \mathrm{Zn}_{\mathrm{y}} \mathrm{Cu}_{3-\mathrm{y}} \mathrm{O}_{10-\delta}(\mathrm{y}=2,3)$ superconductors.

\begin{tabular}{|c|c|c|c|c|c|c|c|c|c|c|c|c|c|}
\hline Sample & $\begin{array}{l}\xi_{c}(0) \\
(\AA)\end{array}$ & $\mathrm{J}$ & $\mathbf{N}_{G}$ & $\begin{array}{l}\lambda_{p . d} \times \\
10^{2} \\
(\AA)\end{array}$ & $\begin{array}{l}\mathrm{B}_{\mathrm{c} 0} \\
(\mathrm{~T})\end{array}$ & $\begin{array}{l}\mathrm{B}_{\mathrm{c} 1} \\
(\mathrm{~T})\end{array}$ & $\begin{array}{l}\mathrm{B}_{\mathrm{c} 2} \\
(\mathrm{~T})\end{array}$ & K & $\begin{array}{l}\mathrm{J}_{\mathrm{c}(0)} \mathrm{X} \\
10^{3} \\
\left(\mathrm{~A} / \mathrm{cm}^{2}\right)\end{array}$ & $\begin{array}{l}V_{F} x \\
10^{7} \\
(m / s)\end{array}$ & $\begin{array}{l}E_{\text {Break }} \\
(\mathrm{eV})\end{array}$ & $\begin{array}{l}\tau_{\varphi} x \\
10^{-13} \\
(s)\end{array}$ & \\
\hline$y=0$ & & 2.090 & 0.077 & 0.048 & 846.87 & 1.716 & 0.089 & 127.70 & 51.99 & 1.099 & 1.797 & 0.0198 & 2.0529 \\
\hline$y=2$ & & 2.140 & 0.080 & 0.052 & 914.09 & 1.593 & 0.077 & 127.70 & 58.19 & 0.941 & 1.705 & 0.0293 & 1.40394 \\
\hline$y=3.0$ & & 2.26 & 0.091 & 0.051 & 985.92 & 1.475 & 0.068 & 127.70 & 62.55 & 0.812 & 1.769 & 0.0351 & 1.18929 \\
\hline
\end{tabular}

The phonon modes are observed in order to understand the process of high temperature superconductivity because electron-phonon interactions are probably important for superconductivity's mechanism. Oxygen, have highest vibrational amplitude due to its smaller atomic size, is responsible for causing such electron phonon interactions. In the CuTl-1223 unit cell, oxygen phonon modes have been witnessed (above $400 \mathrm{~cm}^{-1}$ ). The infrared absorption bands between 50 and $350 \mathrm{~cm}^{-1}$ in layered cuprate superconductors are thought to be caused by the vibration of $\mathrm{TI}, \mathrm{Cu}, \mathrm{Ca}$ and $\mathrm{Ba}$ atoms, whereas the absorption bands above $400 \mathrm{~cm}^{-1}$ are considered to be caused by the vibration of lighter oxygen atoms of chain, planer, and apical oxygen. Two apical oxygen atoms of type $\mathrm{Tl}-\mathrm{O}_{\mathrm{A}}$ - $\mathrm{Cu}(2)$ and $\mathrm{Cu}(1)-\mathrm{O}_{\mathrm{A}}-\mathrm{Cu}(2)$ are witnessed around 420-460, 480-540 $\mathrm{cm}^{-1}, \mathrm{Cu}(2)$ atom is in superconducting plane and $\mathrm{Cu}(1)$ atom in charge reservoir layer(CRL). $\mathrm{CuO}_{2}$ planar oxygen mode is witnessed around $550-580 \mathrm{~cm}^{-1}$ [31-33]. FTIR measurements of our $\mathrm{Cu}_{0.5} \mathrm{TI}_{0.5} \mathrm{Ba}_{2} \mathrm{Ca}_{2} \mathrm{Cu}_{3} \mathrm{O}_{10-\delta},\left(\mathrm{Cu}_{0.5} \mathrm{TI}_{0.5}\right)$ $(\mathrm{BaCa})(\mathrm{CaMa}) \mathrm{Cu}_{1} \mathrm{Zn}_{2} \mathrm{O}_{10-\delta}$ and $\mathrm{Cu}_{n}{ }_{5} \mathrm{Tl}_{n}(\mathrm{BaCa})(\mathrm{CaMg}) \mathrm{Zn}_{3} \mathrm{O}_{10-\delta}$ samples shown in Fig. $5(\mathrm{a})$. CuO ${ }_{2}$ planar mode continuously softened Loading [MathJax]/jax/output/CommonHTML/jax.js

Page 6/11 
with increasing $\mathrm{Zn}$ doping finally attain $515 \mathrm{~cm}^{-1}$ in $\left(\mathrm{Cu}_{0.5} \mathrm{TI}_{0.5}\right)(\mathrm{BaCa})(\mathrm{CaMg}) \mathrm{Zn}_{3} \mathrm{O}_{10-\delta}$ samples. Although the apical oxygen bond length increases, the influence of the mass of $\mathrm{Zn}$ atoms is obvious in softening of these modes, which is most likely connected with the greater mass of $\mathrm{Zn}(65.38 \mathrm{amu})$ atoms in contrast to $\mathrm{Cu}(63.54 \mathrm{amu})$ atoms. The addition of $\mathrm{Zn}$-atoms at $\mathrm{Cu}$ sites in the $\mathrm{CuO}_{2}$ plane is indicated in the variation of modes.

From Fig. 5(b,c), FTIR absorption measurements of samples $\left(A_{y} \mathrm{TI}_{1-y}\right)(\mathrm{BaCa})(\mathrm{CaMg}) \mathrm{Zn}_{3} \mathrm{O}_{10-\delta}(\mathrm{A}=\mathrm{Ni}, \mathrm{K}, \mathrm{Ag}, \mathrm{Mn} ; \mathrm{y}=0,0.5)$ the phonon's modes associated to the vibrations of different oxygen atoms have been observed between $400-700 \mathrm{~cm}^{-1}$. Presence of modes at some different wavenumber as compared to CuTI-1223 system can be attributed to the modified layer of charge reservoir layer $\mathrm{Cu}_{0.5} \mathrm{TI}_{0.5}(\mathrm{BaCa}) \mathrm{O}_{4-\delta}$. Although the position of modes is determined from the bonding among attached atoms. The larger sizes atom of thallium $\mathrm{TI}\left(1.4 \mathrm{~A}^{\circ}\right)$ in the charge reservoir layer $(\mathrm{CRL}) \mathrm{TI}_{0.5} \mathrm{TI}_{0.5}(\mathrm{BaCa}) \mathrm{O}_{4-\delta}$ possibly increase the size of a-axis. The central presence of $\mathrm{TI}^{3+}$ in CRL shows high stability of O-atom. Thallium content in the CRL make it insulating and in the superconducting layer free carriers concentration decrease. Since Thallium is a heavy atom its modes has lowest energy and apical oxygen modes move toward lower wavenumber. $\operatorname{ln~TI}_{1}(\mathrm{BaCa})(\mathrm{CaMg}) \mathrm{Zn}_{3} \mathrm{O}_{10-\delta}$ sample both apical oxygen modes of type $\mathrm{Tl}_{-} \mathrm{O}_{\mathrm{A}}-\mathrm{Zn}(2)$ are witnessed about $486 \mathrm{~cm}^{-1}$ and $521 \mathrm{~cm}^{-1}$.

We prepared $\mathrm{Ni}_{0.5} \mathrm{TI}_{0.5}(\mathrm{BaCa})(\mathrm{CaMg}) \mathrm{Zn}_{3} \mathrm{O}_{10-\delta}$ and $\mathrm{K}_{0.5} \mathrm{TI}_{0.5}(\mathrm{BaCa})(\mathrm{CaMg}) \mathrm{Zn}_{3} \mathrm{O}_{10-\delta}$ samples. When we doped $\mathrm{CRL}$ with heavy atoms like $\mathrm{Ni}\left(1.62 \mathrm{~A}^{0}\right)$ and $\mathrm{K}\left(2.03 \mathrm{~A}^{\circ}\right)$ the apical oxygen modes of type TI- $\mathrm{O}_{A^{-}} \mathrm{Zn}(2)$ slightly change nearly $482 \mathrm{~cm}^{-1}$ and $480 \mathrm{~cm}^{-1}$ while $\mathrm{M}-\mathrm{O}_{A}-\mathrm{Zn}(2)$, where $\mathrm{M}=\mathrm{Ni} / \mathrm{K}$ is observed around $450 \mathrm{~cm}^{-1}$ and $444 \mathrm{~cm}^{-1}$. These softening of apical mode is due to variation in planer frequency of apical modes this reflects the substitution of $\mathrm{K}$ and $\mathrm{Ni}$ at $\mathrm{Cu}$ sites in $\mathrm{CRL} \mathrm{K}_{0.5} \mathrm{TI}_{0.5}(\mathrm{BaCa}) \mathrm{O}_{4-\delta}$ and $\mathrm{Ni}_{0.5} \mathrm{TI}_{0.5}(\mathrm{BaCa}) \mathrm{O}_{4-\delta}$. Similarly when lighter atom like $\mathrm{Mn}\left(1.40 \mathrm{~A}^{\circ}\right)$ and $\mathrm{Ag}\left(1.34 \mathrm{~A}^{\circ}\right)$ is substituted in charge reservoir layer $\mathrm{Mn}_{0.5} \mathrm{TI}_{0.5}(\mathrm{BaCa}) \mathrm{O}_{4-\delta}$ and $\mathrm{Ag}_{0.5} \mathrm{TI}_{0.5}(\mathrm{BaCa}) \mathrm{O}_{4-\delta}$ then peak position of apical oxygen mode $\mathrm{TI}_{-} \mathrm{O}_{\mathrm{A}}-\mathrm{Zn}(2)$ and $\mathrm{M}-\mathrm{O}_{\mathrm{A}}-\mathrm{Zn}(2)$ where $\mathrm{M}=\mathrm{Ag} / \mathrm{Mn}$ move to high wave number. This verifies our conclusion that as the $\mathrm{C}$-axis length decreases, the bond length of the apical oxygen mode decreases, allowing this mode to vibrate at a high wave number. Variation in oxygen related apical modes advises the incorporation of $\mathrm{K}, \mathrm{Ni}, \mathrm{Ag}$ and $\mathrm{Mn}$ in $\mathrm{CRL}$.

\section{Conclusion}

$\left(\mathrm{Cu}_{0.5} \mathrm{TI}_{0.5}\right) \mathrm{Ba}_{2} \mathrm{Ca}_{2} \mathrm{Cu}_{3} \mathrm{O}_{10-\delta},\left(\mathrm{Cu}_{0.5} \mathrm{TI}_{0.5}\right)(\mathrm{BaCa})(\mathrm{CaMg}) \mathrm{Cu}_{1} \mathrm{Zn}_{2} \mathrm{O}_{10-\delta},\left(\mathrm{Cu}_{0.5} \mathrm{TI}_{0.5}\right)(\mathrm{BaCa})(\mathrm{CaMg}) \mathrm{Zn}_{3} \mathrm{O}_{10-\delta}$ and $\left(\mathrm{A}_{\mathrm{y}} \mathrm{TI}_{1-\mathrm{y}}\right)(\mathrm{BaCa})(\mathrm{CaMg})$ $\mathrm{Zn}_{3} \mathrm{O}_{10-\delta}(\mathrm{A}=\mathrm{Ag}, \mathrm{K}, \mathrm{Ni}, \mathrm{Mn} ; \mathrm{y}=0,0.5)$ samples are prepared at normal pressure by employing two-steps solid state reaction method and exhibit orthorhombic crystal structure. Variations in unit cell volume and phonon modes linked to the vibrations of planar and apical oxygen atoms are softened, these findings demonstrate incorporation of $\mathrm{Ca}, \mathrm{Mg}$ and $\mathrm{Zn}$ in the unit cell. Temperature dependence of resistivity plots exhibited suppression in Tc. Above $77 \mathrm{~K}$, samples $\left(\mathrm{Cu}_{0.5} \mathrm{TI}_{0.5}\right)(\mathrm{BaCa})(\mathrm{CaMg}) \mathrm{Zn}_{3} \mathrm{O}_{10-\delta}$ without CuO2 planes showed superconducting activity. We prepared $\left(\mathrm{A}_{\mathrm{y}} \mathrm{Tl}_{1-\mathrm{y}}\right)(\mathrm{BaCa})(\mathrm{CaMg}) \mathrm{Zn}_{3} \mathrm{O}_{10-\delta}(\mathrm{A}=\mathrm{Ag}, \mathrm{K}, \mathrm{Ni}, \mathrm{Mn} ; \mathrm{y}=0,0.5)$ types of samples to demonstrate the contribution of $\mathrm{Cu}\left(3 \mathrm{~d}^{9}\right)$ atoms in superconductivity. Doping $\mathrm{Ni}, \mathrm{Mn}, \mathrm{K}$, and $\mathrm{Ag}$ ions instead of $\mathrm{Cu}$-atoms in the $\left(\mathrm{Cu}_{0.5} \mathrm{Tl}_{0.5}\right) \mathrm{Ba}_{2} \mathrm{O}_{4-\delta} \mathrm{CRL}$ totally eliminates superconductivity and results in semiconducting behavior. Theoretical prediction for the Mott-VRH mechanism is applied to measure the energy of activation for $\mathrm{TI}_{1.0}(\mathrm{BaCa})(\mathrm{CaMg}) \mathrm{Zn}_{3} \mathrm{O}_{10-\delta}, \mathrm{Tl}_{0.5} \mathrm{Ag}_{0.5}(\mathrm{BaCa})(\mathrm{CaMg}) \mathrm{Zn}_{3} \mathrm{O}_{10-\delta}, \mathrm{Tl}_{0.5} \mathrm{~K}_{0.5}(\mathrm{BaCa})$ (CaMg) $\mathrm{Zn}_{3} \mathrm{O}_{10-\delta}, \mathrm{Tl}_{0.5} \mathrm{Ni}_{0.5}(\mathrm{BaCa})(\mathrm{CaMg}) \mathrm{Zn}_{3} \mathrm{O}_{10-\delta}$, and $\mathrm{TI}_{0.5} \mathrm{Mn}_{0.5}(\mathrm{BaCa})(\mathrm{CaMg}) \mathrm{Zn}_{3} \mathrm{O}_{10-\delta}$, sample having values $1.85 \mathrm{meV}, 1.41 \mathrm{meV}$, $2.35 \mathrm{meV}, 2.34 \mathrm{meV}$ and $6.89 \mathrm{meV}$ respectively. The Lawrence and Doniach (LD) model expression were used to compute the parameters like $\mathrm{J}_{\mathrm{c}}(0), \mathrm{B}_{\mathrm{c}(0)}, \mathrm{B}_{\mathrm{c} 1(0)}, \mathrm{B}_{\mathrm{c} 2(0)}$, and $\mathrm{k}=\lambda / \xi$ for $\left(\mathrm{Cu}_{0.5} \mathrm{TI}_{0.5}\right) \mathrm{Ba}_{2} \mathrm{Ca}_{2} \mathrm{Cu}_{3} \mathrm{O}_{10-\delta}$ and $\left(\mathrm{Cu}_{0.5} \mathrm{TI}_{0.5}\right)(\mathrm{BaCa})(\mathrm{CaMg})\left(\mathrm{Cu}_{3-\mathrm{x}} \mathrm{Zn}_{\mathrm{x}}\right) \mathrm{O}_{10-\delta}(\mathrm{x}=2,3)$ samples. In our samples the values of $J_{c}(0), B_{c 0}(T), B_{c 1}(T)$ suppress. The number of unintended defects, calculated by parameter a in

samples enhanced with increasing $Z n$-doping, decrease in $B_{c(0)}, B_{c 1(0)}, B_{c 2(0)}, J_{c}(0)$ values indicate that these defects are not behaving as pinning centres shows that the London penetration depth $\lambda_{p . d}$ and the $G L$ parameter increase in all doped samples. The $\mathrm{Cu}\left(\mathrm{d}_{\mathrm{x}}{ }^{2}-\mathrm{y}^{2}\right)$ orbital's energy is almost degenerate with that of the $O(2 p)$ orbitals in cuprates, making hybridization and hence spin fluctuation extremely strong. The energy levels of the $\mathrm{Ni}, \mathrm{Ag}, \mathrm{K}, \mathrm{Mn}$, and $\mathrm{O}$ orbitals, on the other hand, are quite different, weakening the spin fluctuations.

\section{References}

1. D. $L i<\mathrm{bi}>\mathrm{et}$ al., </bi Nature $572<\mathrm{bi}>,</ \mathrm{bi}>624<\mathrm{bi}>(</ \mathrm{bi}>2019<\mathrm{bi}>)</ \mathrm{bi}>$

2. A. \&hilling, M. Cantoni, J.D. Guo, and H.R. Ott, Nature 362 (1993) 56.

3. Phvsical Pronerties of Hiah Temnerature Superconductors, Vol. 1-4, D.M. Ginzbetg (World Scientific, Singapore). Loading [MathJax]/jax/output/CommonHTML/jax.js 
4. H. Ihara, Phys. C 364 (2001) 289

5. A.A. Khurram, Nawazish A. Khan, J. Electromagn. Anal. Appl. 2 (2010) 63

6. C. Park, R.L. Synder, J. Am. Ceram. Soc.78 (1995) 3171.

7. H. Ihara, A. Iyo, K. Tanaka, K. Tokiwa, K. Ishida, N. Terada, M. Takumoto, Y. Sekita, T. Tsukamoto, T. Watanabe, M. Umeda,Physica C 282-287 (1997) 1973.

8. Y. Shimakawa, J.D. Jorgensen, H. Shaked, R.L. Hitterman, T. Kondo, T. Manako, Y. Kubo, Phys. Rev. B 51 (1995) 568.

9. H. Eisaki, N. Kaneko, D. L. Feng, A. Damascelli, P. K. Mang, K. M. Shen, Z. X. Shen, and M. Greven, "Effect of chemical inhomogeneity in bismuth-based copper oxide superconductors," Phys. Rev. B, vol. 69, p. 064512, Feb 2004.

10. P. Fulde, Electron Correlations in molecules and solids. Springer-V erlag Berlin Heidelberg GmbH, 1995.

11. See, for example, J. Phys. Chem. Solids, 54, No. 10 (1993)

12. SM. Quinlan, D.J. Scalapino and N. Bulut, Phys. Rev. B 49 (1994) 1470

13. D.S. Rokhsar, Phys. Rev. Lett. 70 (1993) 493.

14. R.B. Laughlin, Proc. Summer School on Modem Perspectives in Many-Body Physics, Canberra, Jan. 1993 (World Scientific, Singapore).

15. J.G. Hobor, W.J. Liverman, Y. Xu, A.R. Moodenbaugh, Phys. Rev. B 41(1990) 8757.

16. Y. Matsumoto, M. Koinuma, H. Yamamoto, T. Nishimori, Solid State lonics 95(1997) 309-314.

17. G. Bergmann, Phys. Rep., 1984, 107, 1-58.

18. J. Ren, H. Guo, J. Pan, Y. Y. Zhang, X. Wu, H. G. Luo, S. Du, S. T. Pantelides and H. J. Gao, Nano Lett., 2014, 14, 4011-4015.

19. J. H. Chen, L. Li, W. G. Cullen, E. D. Williams and M. S. Fuhrer, Nat. Phys, 2011, 7, 535-538.

20. A. Mourachkine, High-Temperature Superconductivity in Cuprates: The Nonlinear Mechanism and Tunneling Measurements (Dordrecht, Kluwer Academic, 2002).

21. B. Keimer et al., Nature 518, 179 (2015)

22. R. Mark Wilson: Physics Today 72, 11, 19 (2019)

23. Q.G. Luo, R.Y. Wang, J.Phys Chem Sol. 87 (1987) 90102-90108

24. Aslamazov L G and Larkin A L 1986 Phys. Lett. 26283

25. W.E.L. Doniach, in: Eizo, Kanda (Eds.), Proceedings of the Twelfth International Conference on Low Temperature Physics, Keigaku, Tokyo, 1971, p. 361.

26. S. Hikami, A.I. Larkin, Magneto resistance of high temperature superconduc tors,Mod. Phys. Lett. B 2 (1988) 693-698.

27. J. Ali, S. Hussain, N. A. Khan, A. Raza, J. Supercond. Nov. Magn, 33 (2019) 1557-1939.

28. Nawazish A. Khan, A. A. Khurram, Appl. Phys. Lett. 86, 152502 (2005).

29. A.I. Abou Aly, I.H. Ibrahim, R. Awad, A. El-Harizy, A. Khalaf, J. Supercond. Nov.Magnetism 23 (2010) 1325-1332.

30. M.P. Rojas Sarmiento, M.A. Oribe Laverde, E. Vera Lopez, D.A. Landinez, J. Roa Rojas, Conductivity, Phys. B Condens. Matter 398 (2007) 360-363.

31. J. Prade, A.D. Kulkarani, F.W. de wette, Phys. Rev. B 39 (1989) 2771.

32. A.D. Kulkarani, J. Prade, F.W. de wette, W. Kress, U. Schroder, Phys. Rev. B 40(1989) 2642.

33. W. Kress, U. Schroder, J. Prade, A.D. Kulkarani, F.W. de wette, Phys. Rev. B 38(1988) 2906.

\section{Figures}



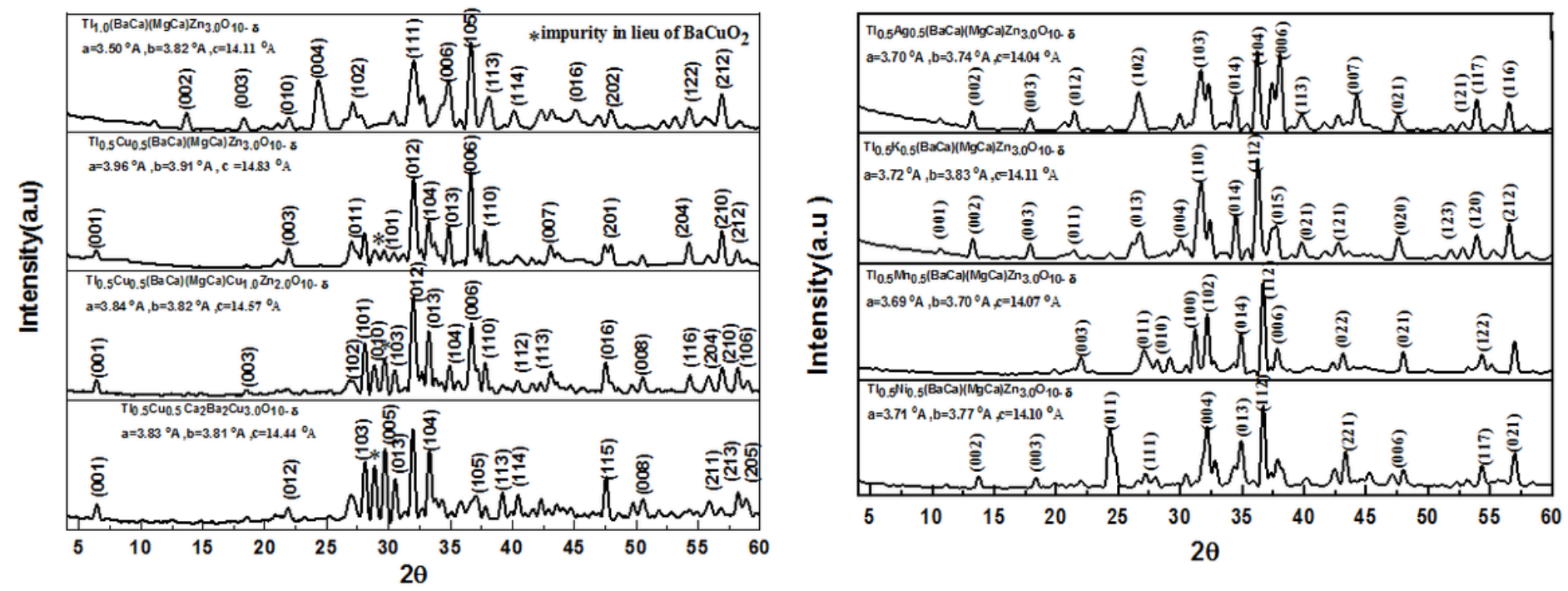

Figure 1

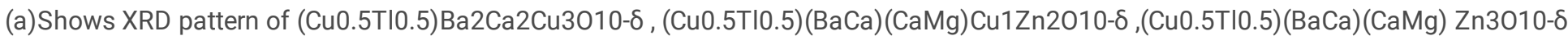

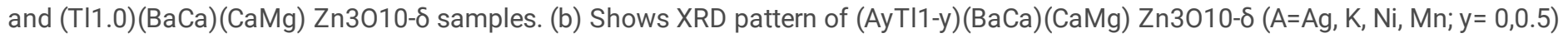
samples
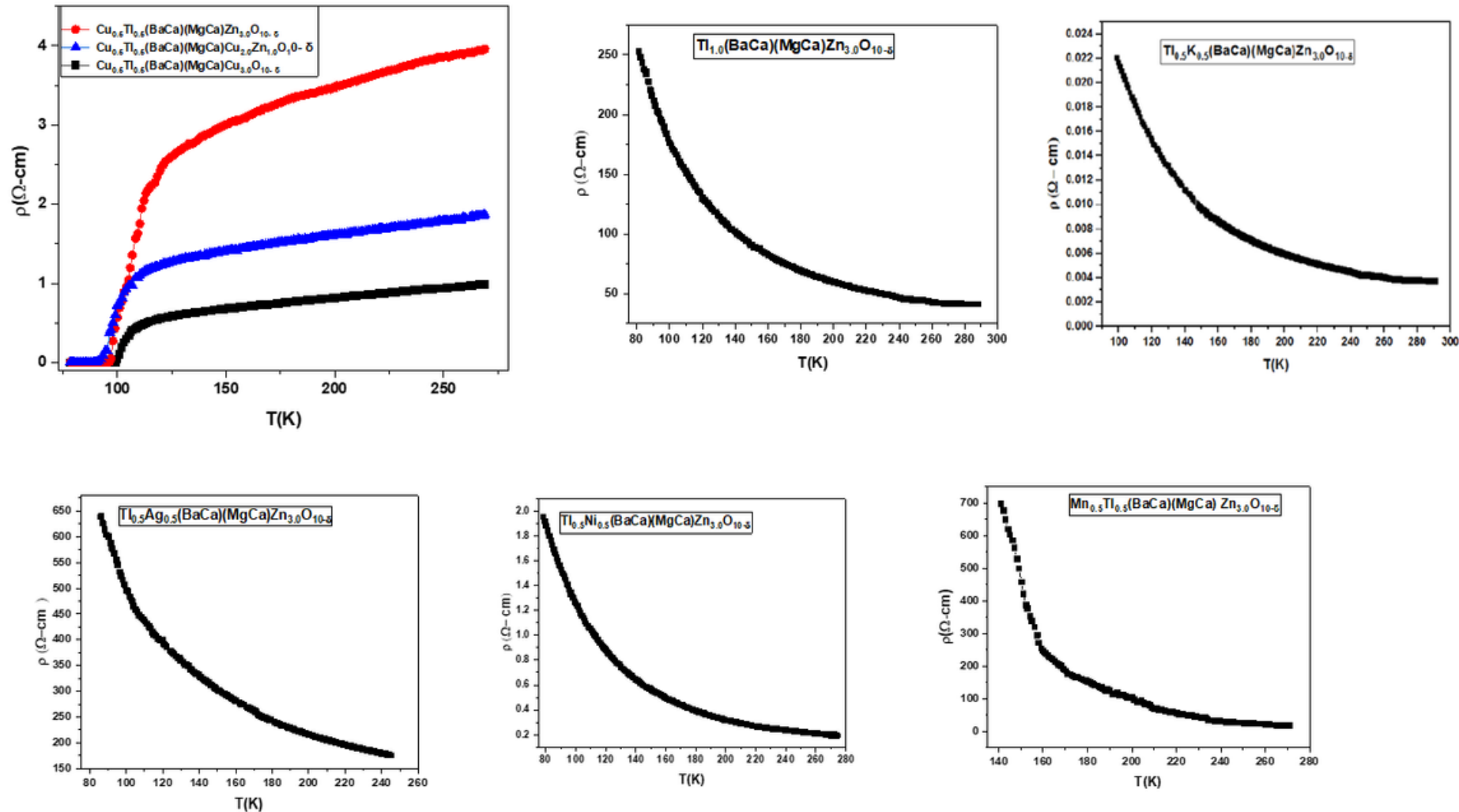

Figure 2

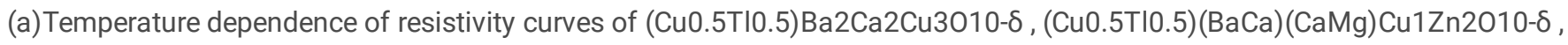

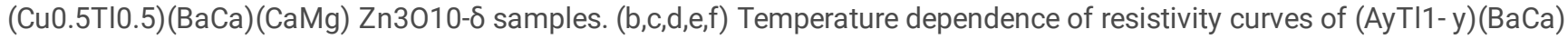
$(\mathrm{CaMg}) Z n 3010-(\mathrm{A}=\mathrm{Ag}, \mathrm{K} ; \mathrm{y}=0,0.5)$ samples. 

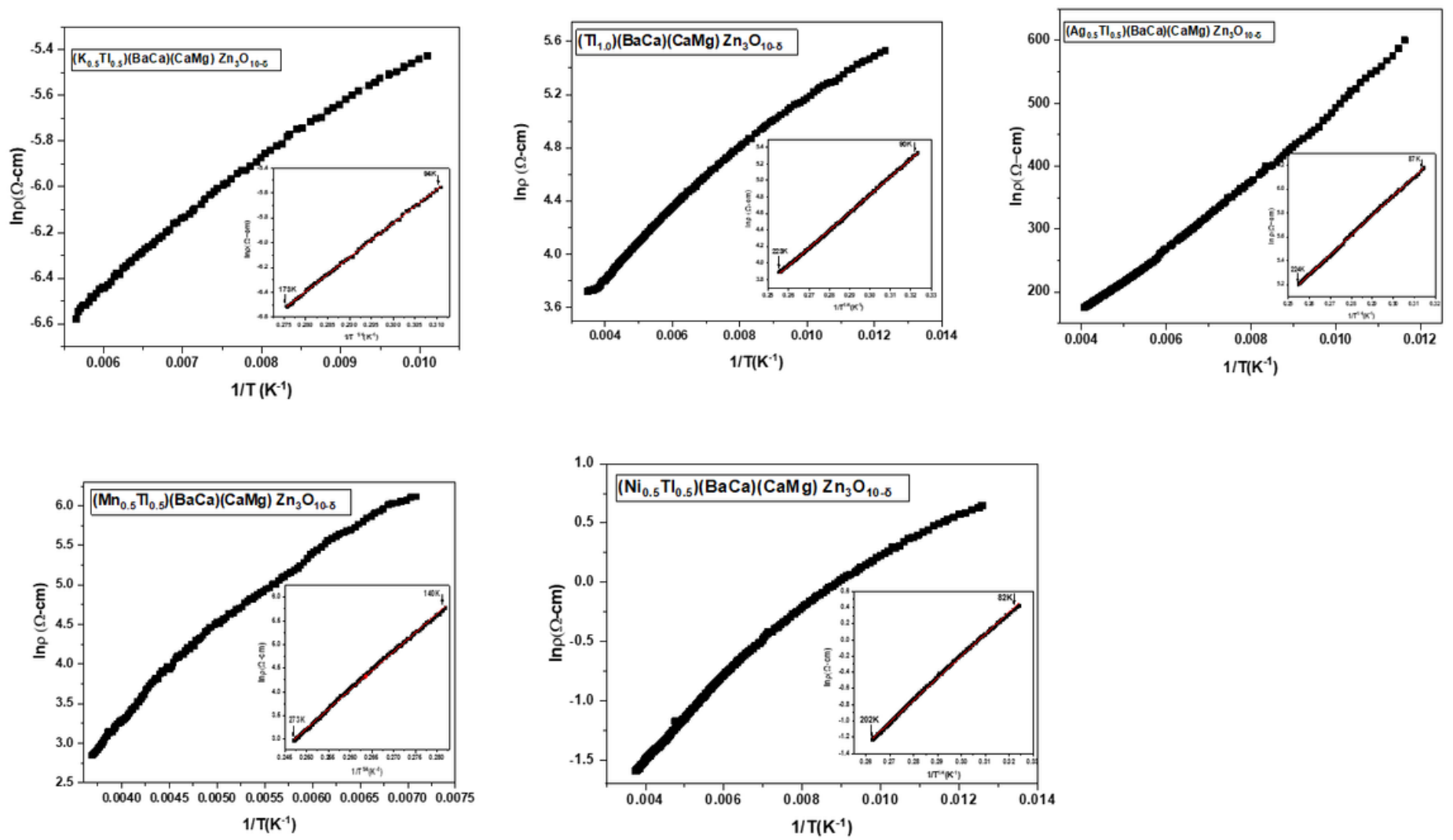

\section{Figure 3}

$(a, b, c, d, e)$ Log of Electrical resistivity (In $\rho)$ as a function of $1 / \mathrm{T}$ in the temperature range from $77 \mathrm{~K}$ to $300 \mathrm{~K}$. The inset represents the plot of In $\rho$ vs. 1/T1/4, where the theoretical prediction for the Mott-VRH mechanism is indicated by the straight line of $(\mathrm{AyTl1}-\mathrm{y})(\mathrm{BaCa})(\mathrm{Ca}$ Mg) Zn3010- (A= Ag, K, Ni, Mn; y= 0, 0.5) samples.
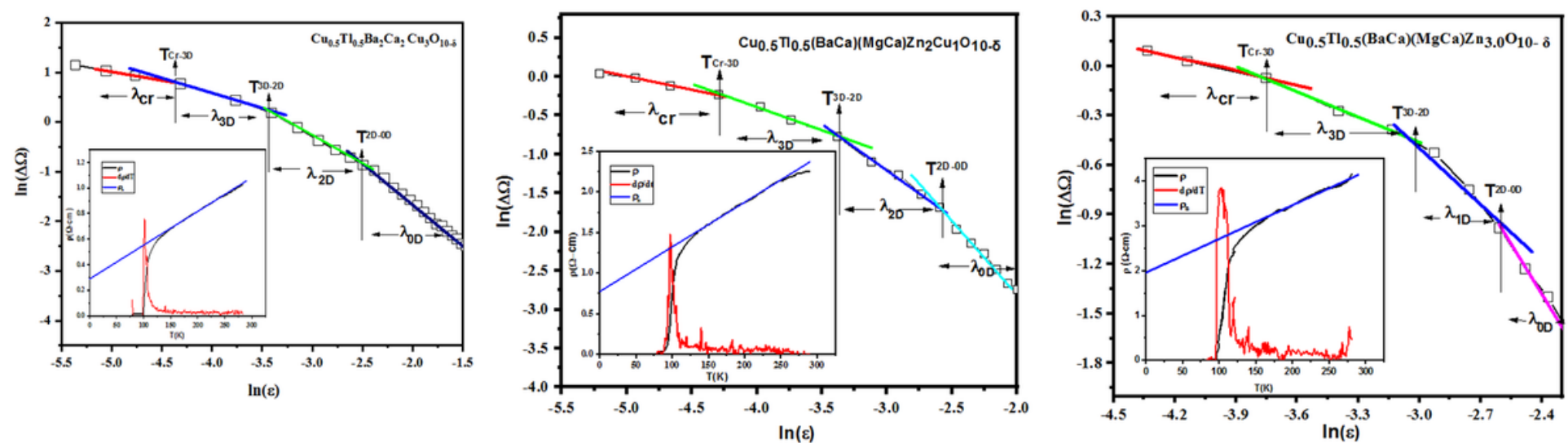

Figure 4

$(\mathrm{a}, \mathrm{b}, \mathrm{c})$ Show the typical representation of the excess conductivity analysis of Cu0.5TI0.5Ba2Ca2Cu3010- $\delta$ and Cu0.5TI0.5(BaCa)

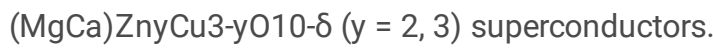



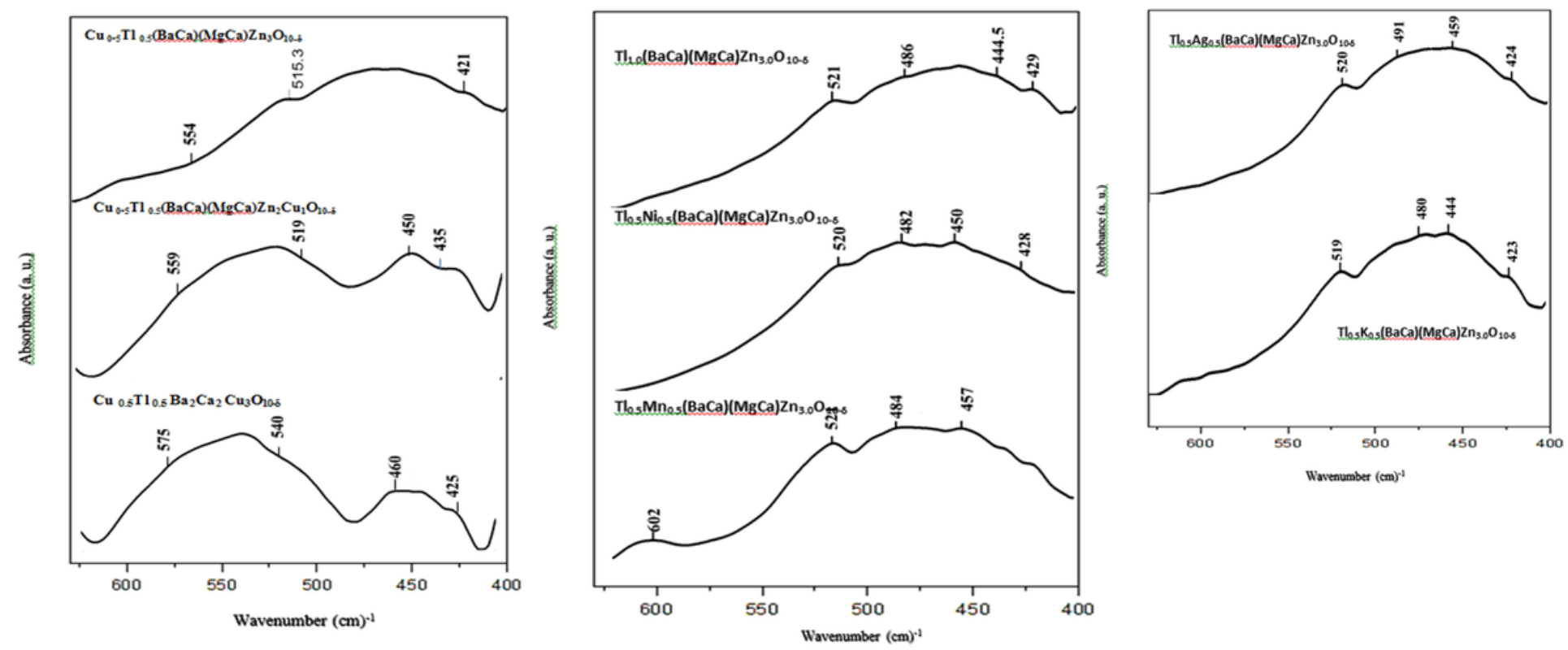

\section{Figure 5}

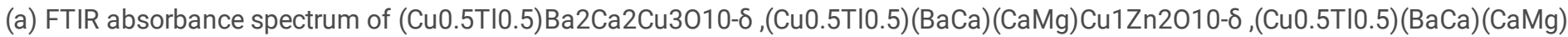
Zn3010- $\delta$ samples. (b) FTIR absorbance spectrum of (TI1)(BaCa)(CaMg)Zn3010-, (Ni0.5TI0.5)(BaCa)(CaMg)Zn3010- and (Mn0.5TI0.5) (BaCa)(Ca Mg) Zn3010-samples. (c) FTIR absorbance spectrum of (K0.5TI0.5)(BaCa)(Ca Mg) Zn3010- and (Ag5TI0.5)(BaCa)(Ca Mg) Zn3010- samples. 